\title{
Zerwanie szóstej pieczęci i „dzień wielki gniewu ich" (Ap 6, 17)
}

\author{
Mirosław Rucki \\ Uniwersytet Technologiczno-Humanistyczny im. Kazimierza Pułaskiego w Radomiu \\ miroslaw.rucki@gmail.com (D) http://orcid.org/0000-0001-7666-7686
}

Karol Szymański

Poznań

karoszym@wp.pl @ https://orcid.org/0000-0002-5562-2603

\section{Michael Abdalla}

Uniwersytet im. Adama Mickiewicza w Poznaniu

masatur@amu.edu.pl (1) https://orcid.org/0000-0002-0933-3755

Księga Apokalipsy pozostaje dla wielu księgą przerażającą ${ }^{1}$. Zawarte w niej wizje tak bardzo przemawiają do wyobraźni, że w języku codziennym słowo „apokalipsa” zaczęło oznaczać katastrofalne zjawisko. Tymczasem Apokalipsa jest jedną z wielu ksiąg objawionych, dzięki którym człowiek może poznawać Boga przez Jezusa Chrystusa dzięki Jego Duchowi. Bóg sam w sobie jest tajemnicą nieprzeniknioną, a wszystko, co człowiek wie na Jego temat, zostało mu objawione, odsłonięte, ukazane $\mathrm{e}^{2}$. W tradycji biblijnej to odsłonięcie tajemnicy jest określane hebrajskim słowem șisala, któremu odpowiada greckie

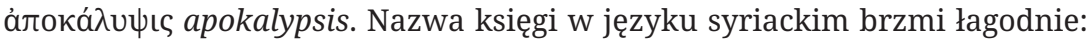

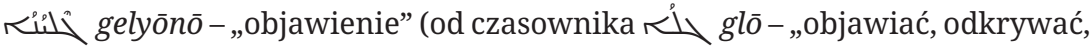

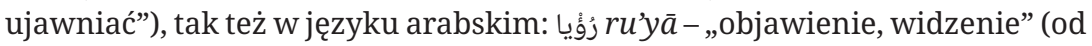
czasownika رَأَ ra’a - „widzieć, objawić, ukazywać”).

Pomimo licznych trudności interpretacyjnych zasadnicze przesłanie Apokalipsy jest zrozumiałe. Klinkowski podkreśla, że symbole w Apokalipsie tworzą obraz wielowymiarowej rzeczywistości jak w mozaice: kiedy się stoi

1 D. Kotecki, Kościół w świetle Apokalipsy św. Jana, Częstochowa 2008, s. 14.

2 M. Rucki, K. Szymański, Monotrynitarne powitanie w Apokalipsie, „Scriptura Sacra” 19 (2015), s. 183-197. 
za blisko, nie widać całości, ale jeśli się stoi za daleko, można zgubić znaczenie detali ${ }^{3}$.

Naumowicz odnotowuje, że najwcześniejsza tradycja niemal jednomyślnie przyjmuje pochodzenie Apokalipsy z czasów apostolskich oraz autorstwo Jana Ewangelisty, zaś pierwsze wątpliwości pojawiły się na przełomie II i III wieku w związku z kwestiami interpretacyjnymi ${ }^{4}$. W odróżnieniu od autorów pseudonimicznej literatury apokaliptycznej judaizmu przypisujących swoje dzieła wielkim postaciom przeszłości (Henoch, Baruch, Abraham, Mojżesz), autor Apokalipsy podaje swoje imię i występuje jako świadek prawdomówny ${ }^{5}$. Dodaje to wiarygodności całemu przesłaniu księgi, dlatego $\mathrm{w}$ analizie przyjmujemy autorstwo Jana.

Andrzej z Cezarei (przełom VI i VII wieku) rozumiał Apokalipsę w taki sposób, że Bóg objawił św. Janowi rzeczy, które są i które staną się, aby zachęcić i przekonać wszystkich ludzi do pokuty i nawrócenia ${ }^{6}$. Objawienie zawarte w Księdze Apokalipsy sugeruje, że z osobą Jezusa Chrystusa łączy się jakaś tajemnica, którą można odkryć, czytając tę księgę ${ }^{7}$. Zazwyczaj wiele uwagi poświęca się zwycięstwu Baranka i Jego chwale, a także roli, jaką odegrał w zbawieniu ludzi, oraz Jego uczcie weselnej ${ }^{8}$, zaś mało kto skupia się na zagadnieniu gniewu Baranka. Niniejsze studium ma na celu przynajmniej częściowe wypełnienie tej luki.

\section{Zerwanie szóstej pieczęci}

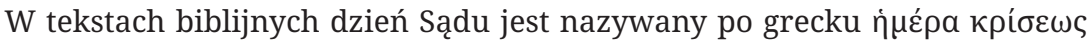
hemera kriseos (np. Mt 10, 15), zaś w Biblii Hebrajskiej jest określany mianem

3 Apokalipsa, tł., koment. i miejsca paralelne H. Langkammer, zagadnienia wstępne i bibliogr. J. Klinkowski, Lublin 2010, s. 40 (Biblia Lubelska. Pismo Święte Starego i Nowego Testamentu w Przekładzie z Języków Oryginalnych).

4 J. Naumowicz, Pierwsze interpretacje Apokalipsy, [w:] Pierwsze łacińskie komentarze do Apokalipsy. Hipolit, Wiktoryn, Hieronim, Tykoniusz, pod red. D. Budzanowskiej, W. Linke, Warszawa 2011, s. 7-48.

5 J. Klinkowski, Tło narodzin apokaliptyki, [w:] Apokalipsa, dz. cyt., s. 8-37.

6 A. Jasiewicz, Interpretacja „Komentarza do Apokalipsy” Andrzeja z Cezarei i jego znaczenie dla krytyki tekstu biblijnego, „Biblica et Partistica Thoruniensia” 5 (2012), s. 163-173, https://doi. org/10.12775/BPTh.2012.009.

7 D. Kotecki, Jezus a Bóg Izraela w Apokalipsie św. Jana, Toruń 2013, s. 13.

8 Np. zagadnieniom tym poświęcona jest znaczna część materiałów konferencji: Symposium on Revelation Introductory and Exegetical Studies, Book 1-2, ed. F. B. Holbrook, Silver Spring 1992. 
dnia Pańskiego (hebr. י jom JHWH) lub po aramejsku po prostu Sądu דִ דִינָא dina (w Dn 7, 10.22. 26). Szczególnie w księgach prorockich można zauważyć, że jest on jakby podzielony na dwa odrębne wydarzenia: odkupienie, którego obrazem jest Jom Kippur z jego systemem ofiarniczym, oraz gniew opisywany jako przerażający dzień gniewu (ףאֵ jom af) związany z destrukcją całego świata materialnego i totalną zagładą ludzi. Gniew następuje dopiero po dokonaniu przez Boga odkupienia, z którego ludzie mogą skorzystać lub nie.

Proces sądowy obserwowany przez św. Jana zaczyna się od otwarcia ważnego dokumentu, mającego wielkie znaczenie w sprawie. Dokument ten jest zapieczętowany, więc otwarcie go oznacza złamanie siedmiu pieczęci (Ap 6, 1-17). W zrozumieniu sensu objawienia zawsze pomagają odniesienia do realiów znanych autorowi; dotyczy to również „wizji siedmiu pieczęci”, choć tutaj odwołanie się do realiów nie jest aż tak dosłowne ${ }^{10}$.

Obrzęd otwierania zapieczętowanego zwoju wymagał zgromadzenia niebiańskiego trybunału, który został opisany przez św. Jana. W starożytnym Izraelu zapieczętowany zwój był otwierany z reguły z podczas posiedzenia sądu, kiedy dokument mógł podlegać zakwestionowaniu. Podobna sytuacja miała miejsce w relacji proroka Jeremiasza (Jr 32). Talmud zawiera ciekawą opinię rabbiego Jochanana na temat potopu (Sanhedryn, 108a), w której używa on zwrotu: „decyzja o wymierzeniu kary została zapieczętowana”, czyli odłożona do pewnego czasu. Z kontekstu wynika, że dopiero złamanie pieczęci ujawniło zapis związany z karą, i w konsekwencji nastąpił potop. $\mathrm{W}$ innej dyskusji rabini wspomnieli o zapieczętowanym zwoju z wyrokiem ułaskawiającym. Omawiając zagadnienie bałwochwalstwa, które doprowadziło do klęski Izraela i wygnania babilońskiego, rabbi Jehuda powiedział:

Wtedy pościli przez trzy dni, błagając o miłosierdzie, i spadł z nieba zwój z wyrokiem, na którym wypisane było słowo אמת emet (,prawda”). Rabbi Hanina powiedział: z tego wynika, że pieczęć Świętego, błogosławiony On, jest prawdą (Sanhedryn, 64a).

Wielu interpretatorów postrzega pieczęci jako Boże sądy nad ziemią, ale taka interpretacja pomija kontekst oraz cel całej wizji. Pieczęci strzegą bowiem zwoju, a ich zerwanie ma na celu jego otwarcie i objawienie tego, co

9 Ze względu na szacunek dla Imienia Bożego, by nie dopuścić do „poniżenia Imienia”, żydzi stosują zamiast tetragramu JHWH skrótowy zapis "?.

10 H. Langkammer, Apokalipsa św. Jana. Realia archeologiczno-historyczne w wizjach i symbolice, Wrocław 2010, s. 6. 
sam zwój zawiera. Jednak Janowi nie zostało dane ujrzeć jego zawartości, a jedynie samo zrywanie pieczęci. I choć wraz z każdą złamaną pieczęcią oglądał on dramatyczne sceny oraz słyszał głosy tak niebiańskie, jak i ziemskie (Ap 6, 5. 10.16-17), nie podaje, kiedy sam zwój miał zostać otwarty. Proces usuwania pieczęci okazał się długotrwały i towarzyszyło mu wiele przerażających zjawisk oraz wydarzeń na niebie i na ziemi.

W poprzedzającym badane wersety rozdziale Apokalipsy jest mowa o tym, że całe niebo oczekiwało na kogoś, kto byłby godzien złamać pieczęci i otworzyć księgi, a Jan nawet płakał, że nikogo nie znaleziono (Ap 5, 4). Jezus Chrystus, Baranek Boży, pokonał śmierć i zło poprzez swoją mękę, śmierć i zmartwychwstanie, odnosząc definitywne i nieodwołalne zwycięstwo. Właśnie dzięki temu zwycięstwu Jezus posiada odpowiednie uprawnienia i kwalifikacje, by złamać pieczęci i otworzyć zwój. Można nawet powiedzieć, że Jezus cierpiał i umarł, aby móc otworzyć tę księgę ${ }^{11}$.

Zagadnienie gniewu Baranka pojawia się u św. Jana w związku ze złamaniem szóstej pieczęci. $\mathrm{W}$ analizie należy uwzględnić kontekst wprowadzający Jana do tej wizji, przede wszystkim obraz dusz (gr. భuxàs psychas) znajdujących się pod (úroká $\omega$ hypokato) ołtarzem w niebie. Możliwe, że nawiązuje on do krwi ofiar wylewanej u podstaw ziemskiego ołtarza (zob. np. Wj 29, 12), gdyż prześladowani za wiarę chrześcijanie uważali siebie za owce ofiarne, gotowe w każdej chwili dolać swą krew do ofiar i obrzędu ofiarniczego (Rz 8, 35-37; 2 Tm 4, 6). Znamienne jest, że w stosunku do owych dusz jest

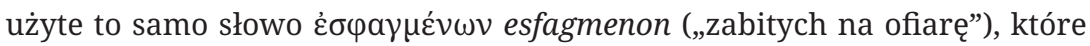
nazywa ofiarę Jezusa jako Baranka (Ap 5,12), tak jakby Bóg postrzegał cierpienie wiernych jako współudział w ofiarniczej śmierci Chrystusa.

Wizja piątej pieczęci koncentruje się na wołaniu zabitych: „Dokądże, Władco święty i prawdziwy, nie będziesz sądził i wymierzał za krew naszą kary tym, co mieszkają na ziemi?” (Ap 6,10). Bóg przyznaje im sprawiedliwość, jednocześnie prosząc, by poczekali jeszcze do odpowiedniego momentu. Każdemu z wierzących przyznano białą szatę, co oznacza dla nich wyrok uniewinniający przyznany im w wyniku już rozpoczętego w niebie postępowania sądowego. Złamanie szóstej pieczęci będzie miało już zupełnie inny charakter, związany z realizacją postanowień sądowych. Dalsze wydarzenia

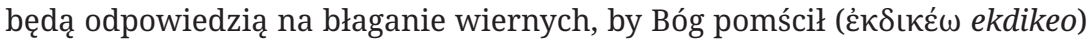
ich krew, i ten proces będzie trwał aż do momentu, kiedy ta krew zostanie

11 D. Kotecki, Jezus a Bóg Izraela w Apokalipsie św. Jana, dz. cyt., s. 301. 
pomszczona (Ap 19, 2). Pamiętajmy jednak, że nie chodzi o zemstę ${ }^{12}$, tylko o wykonanie sprawiedliwych wyroków według rozumowania św. Pawła:

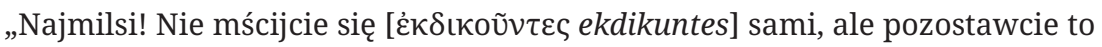

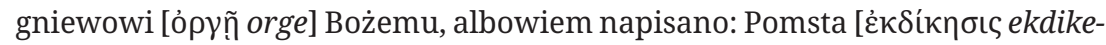
sis] do mnie należy, Ja odpłacę, mówi Pan” (Rz 12, 19 Biblia Warszawska). Jest to dobrze widoczne w tłumaczeniu Peszitty, gdzie użyte zostało aramejskie

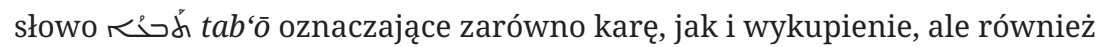
dochodzenie swoich praw na drodze sądowej ${ }^{13}$.

W momencie zerwania szóstej pieczęci Bóg wkracza do historii ludzkości, ale już nie jako potulny baranek złożony na ofiarę i niosący światu miłosierdzie, tylko jako sprawiedliwy sędzia ogłaszający wyroki - a wyroki te są niestety pełne gniewu. Wizja ta została opisana w Apokalipsie w sposób następujący:

I ujrzałem, gdy otworzył pieczęć szóstą, że trzęsienie wielkie powstało i słońce stało się czarne jak wór, i cały księżyc stał się jak krew, i gwiazdy nieba spadły na ziemię, jak drzewo figowe zrzuca swoje figi, gdy wiatr gwałtowny nim wstrząśnie. I niebo oddzielone zostało jak zwój, który się zwija, i wszystkie góry i wyspy poruszone zostały. A królowie ziemi i możnowładcy, i tysięcznicy, i bogacze, i silni, i wszyscy niewolnicy, i wolni ukryli się w jaskiniach i w skałach gór. I mówili górom i skałom: Padnijcie na nas i zakryjcie nas przed obliczem siedzącego na tronie, i od gniewu Baranka, bo nastał dzień wielki gniewu ich, i kto może się ostać? (Ap 6, 12-17) ${ }^{14}$.

Szósta pieczęć określa punkt zwrotny w relacjach między Bogiem a ludzkością. Jeśli wcześniej, na początku swojej Księgi Objawienia, św. Jan widział Boga przerażającego, ale darzącego ludzi wielką życzliwością ${ }^{15}$, to od tego momentu Bóg zachowuje się inaczej. Cała Jego potęga i sprawiedliwość obraca się przeciwko ludziom, którzy nie chcieli nawiązać z Nim relacji, uwzględnić Jego władzy nad światem i odpowiedzieć na Jego miłość nawróceniem. W tym momencie ludzie, którzy żyli w złudzeniu, że Boga nie ma, lub że Bóg nie ma

12 Dokonywanie zemsty było jednoznacznie zabronione przez Prawo Mojżeszowe, co zostało wykazane w rozdziale: M. Rucki, Contradiction between the laws "Thou shalt not avenge" and "An eye for an eye”, [w:] Bible Caught in Violence, ed. C. Korzec, Berlin 2019, s. 49-58.

13 A Compendious Syriac Dictionary, ed. J. Payne Smith, Winona Lake 1998, s. 604.

14 Za: Grecko-polski Nowy Testament. Wydanie interlinearne z kodami gramatycznymi, tł. R. Popowski, M. Wojciechowski, Warszawa 1997.

15 Ukazanie w Apokalipsie Boga jako wszechpotężnego władcy, a jednocześnie bliskiego i życzliwego, omówiono w artykule K. Szymański, M. Rucki, Monotrynitarne powitanie w Apokalipsie, art. cyt., s. 183-197. 
żadnej realnej władzy, napełnieni zostali przerażeniem z powodu bezpośredniego wkroczenia Boga do akcji, wyrażającego się m.in. w zachwianiu całego materialnego świata - który przecież wydawał się być niezachwianym i wiecznym. Wizja Jana ukazuje realne zagrożenie, gdyż tak jak pewna jest możliwość życia wiecznego, tak oczywista jest też groźba poniesienia wiecznej klęski ${ }^{16}$.

Dzień ostatecznego wyzwolenia i oswobodzenia Kościoła Bożego jest jednocześnie dniem gniewu (ỏpyñ orge) Bożego wobec Jego nieprzyjaciół. Wydarzenie to obejmuje cały świat. Gniew Boży zwraca się przeciwko całej ziemi i nawiedza ją w sposób totalny. Jest to wypełnienie wielokrotnie zapowiadanej rzeczywistości, przed którą prorocy i apostołowie zgodnie ostrzegali ludzi: „Oto przez swoją zatwardziałość i serce nieskłonne do nawrócenia skarbisz sobie gniew na dzień gniewu i objawienia się sprawiedliwego sądu Boga” (Rz 2, 5). Gniew ten jest powiązany z odpłatą wynikającą ze sprawiedli-

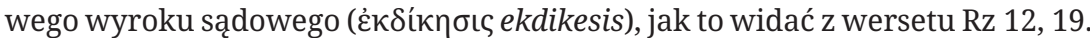
Możemy zauważyć, że zatwardziałość grzesznika wywołuje więcej problemów niż tylko gniew: „tym zaś, którzy są przekorni, za prawdą pójść nie chcą, a od-

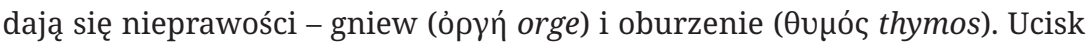

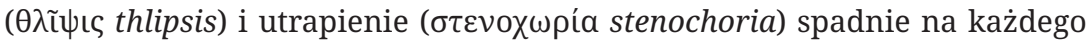
człowieka, który dopuszcza się zła” (Rz 2, 8-9).

Te cztery rzeczy są oddane w różnych tłumaczeniach inaczej:

- gniew i pomsta, utrapienie i ucisk (Biblia Warszawska) ${ }^{17}$,

- $\quad$ zapalczywość i gniew, utrapienie i ucisk (Biblia Gdańska) ${ }^{\mathbf{1 8}}$,

- gniew i wzburzenie, utrapienie i ucisk (Najnowszy Przekład) ${ }^{19}$,

- $\quad$ straszny gniew, ucisk i udręka (Biblia Poznańska) ${ }^{20}$.

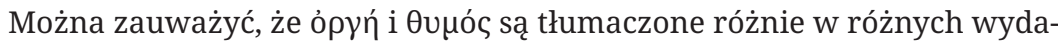
niach, bo ciężko jest dobrać w języku polskim odpowiedniki oddające sens tych greckich wyrazów wskazujących na przerażający, niepowstrzymany,

16 M. Karczewski, Jezioro siarki i ognia w Księdze Apokalipsy św. Jana, „Biblica et Partistica Thoruniensia” 5 (2012), s. 103-113, https://doi.org/10.12775/BPTh.2012.005.

17 Biblia to jest Pismo Święte Starego i Nowego Testamentu, Brytyjskie i Zagraniczne Towarzystwo Biblijne, Warszawa 1975.

18 Biblia to jest całe Pismo Święte Starego i Nowego Testamentu z hebrajskiego i greckiego języka na polski pilnie i wiernie przetłómaczona, Brytyjskie i Zagraniczne Towarzystwo Biblijne, Warszawa 1986.

19 Pismo Święte Starego i Nowego Testamentu. Najnowszy przekład z języków oryginalnych z komentarzem, Święty Paweł, Częstochowa 2008.

20 Pismo Święte Starego i Nowego Testamentu w przekładzie z języków oryginalnych ze wstępami i komentarzami, Księgarnia św. Wojciecha, wyd. 3, Poznań 1999. 
zmiatający wszystko na swojej drodze gniew Boga wywołany przez nasze uporczywe trwanie w grzechu. Moc tego gniewu przyjmuje wręcz materialny wymiar: „Dlatego niebiosa się poruszą i ziemia się wstrząśnie w posadach, na

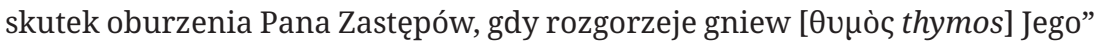
(Iz 13,13). W tym miejscu grecki wyraz jest odpowiednikiem hebrajskiego zwrotu חָרוֹ charon af dosłownie oznaczającego „palący gniew”.

Najwyraźniej św. Paweł nawiązuje w Rz 2, 8-9 do słów Psalmisty: „Zesłał na nich żar swojego gniewu: oburzenie, zapalczywość i udrękę - orszak zwiastunów klęski” (Ps 78, 49). W tabeli przedstawiono tłumaczenie hebrajskich wyrazów odpowiednio na grecki w Septuagincie i na aramejski w Peszitcie:

\begin{tabular}{|c|c|c|c|c|c|c|}
\hline \multicolumn{2}{|c|}{ Biblia Hebrajska } & \multicolumn{2}{|c|}{ Septuaginta } & \multicolumn{2}{|c|}{ Peszitta } & Biblia Tysiąclecia \\
\hline חרון אפו & charon apo & 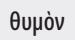 & thymon & سُحنُ & hemtōō d-ruġzō & żar swojego gniewu \\
\hline עברה & ewra & ópyท่v & orgen & 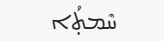 & hemteō & oburzenie \\
\hline וזעם & we-za'am & $\theta \lambda i ̃ \psi ı v$ & thlipsin & K为的 & ruġzō & zapalczywość \\
\hline 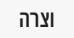 & we-cara & - & - & К & w ulșōnō & i udrękę \\
\hline
\end{tabular}

Ciekawy zabieg zastosowali tłumacze Peszitty, najpierw używając określenia „zapałczywość gniewu”, a potem dając osobno te same wyrazy „zapalczywość” i „gniew”. Tłumaczenie greckie Psalmu 78 pomija słowo „udręka” (צרה cara), które jednak pojawia się u św. Pawła w postaci greckiego

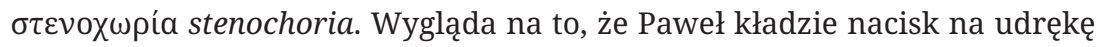
jako na osobiste doświadczenie gniewu Bożego opisanego tymi trzema wyrazami: „żar gniewu”, „oburzenie” i „zapalczywość”. Żaden przekorny ( eritheia - dosł. „zapatrzony w siebie, egoistyczny, dążący do własnej korzyści”) człowiek, o którym pisze Apostoł, nie będzie mógł powiedzieć: „Mnie to nie dotyczy".

Można by było w tym miejscu pominąć rozważania rabiniczne na temat Psalmu 78, dlatego że najprawdopodobniej nie były one znane św. Pawłowi. Chciałoby się jednak przytoczyć je ze względu na przytłaczającą wagę obrazu zawartego w wersecie Ps 78, 49, pobudzającego wyobraźnię rabinów:

Rabbi Jose Galilejczyk mówił: „Jak można udowodnić, że Egipcjanie w Egipcie zostali dotknięci dziesięcioma plagami, nad morzem zaś pięćdziesięcioma? Otóż o plagach w Egipcie zostało 
powiedziane: „I rzekli magowie do faraona: jest w tym palec Boży” (Wyj 8, 15). A o wydarzeniach nad morzem jest powiedziane: „I zobaczyli Izraelici silną pięść, jaką uderzył Bóg Egipcjan, i ulękli się PANA i uwierzyli Jemu i Jego słudze Mojżeszowi” (Wyj 14, 31). Ile plag odpowiada jednemu palcu? Dziesięć. [A ile palców jest w pięści? Pięć.] Stąd wynika, że w Egipcie spadło na nich dziesięć plag, a nad morzem - pięćdziesiąt.

Rabbi Eliezer mówił: „A jak można udowodnić, że każda z dziesięciu plag, jakie Najświętszy, błogosławiony On, zesłał na Egipt, składała się z czterech różnych plag? Jest napisane: „Zesłał na nich żar swojego gniewu: oburzenie, zapalczywość i udrękę - orszak zwiastunów klęski” (Ps 78, 49). Pierwsza plaga - „oburzenie”, druga - „zapalczywość”, trzecia - „udręka”, czwarta plaga - „orszak zwiastunów klęski”. Wynika z tego, że w Egipcie zostali dotknięci czterdziestoma plagami, a nad morzem aż dwustu plagami”.

Rabbi Akiba mówił: „A skąd można wyprowadzić, że każda z dziesięciu plag, jakie Najświętszy, błogosławiony On, zesłał na Egipt, składała się z pięciu różnych plag? Jest napisane: „Zesłał na nich żar swojego gniewu: oburzenie, zapalczywość i udrękę - orszak zwiastunów klęski” (Ps 78, 49). Pierwsza plaga - „żar gniewu”, druga - „oburzenie”, trzecia - „zapalczywość”, czwarta - „udręka”, piąta plaga - „orszak zwiastunów klęski”. Wynika z tego, że w Egipcie zostali dotknięci pięćdziesięcioma plagami, a nad morzem aż dwustu pięćdziesięcioma plagami”21.

Powyższe obrazy pokazują, że „żar gniewu” jest złożoną rzeczywistością, w której mieszczą się kolejne problemy, plagi i klęski. Nie wolno jej lekceważyć, bo „Straszną jest rzeczą wpaść w ręce Boga żyjącego” (Hbr 10, 31).

Po złamaniu szóstej pieczęci w apokaliptycznej wizji św. Jana następuje trzęsienie ziemi, zaćmienie słońca, księżyc przyjmuje barwę krwi, spadają gwiazdy, góry przewracają się, a wyspy znikają (por. Iz 13, 9-13). Zmienia się język poselstwa: zamiast symbolicznych obrazów wskazujących na jakąś rzeczywistość mamy teraz opis samej rzeczywistości materialnego świata doznającego wstrząsu w wyniku palącego gniewu Bożego.

Możemy zauważyć, że ponownie Bóg zaczyna działać i rozpoczyna sąd na wyraźne, konsekwentne żądanie ludu. „Sąd nad bogami Egiptu” nie rozpoczął się wcześniej niż Bóg „usłyszał jęk Izraelitów” i „wspomniał na swoje przymierze” (Wj 6, 5). Tak samo wygląda sytuacja z wołaniem męczenników, którzy nie poddając w wątpliwość obietnic Boga czy realności sądu Bożego, domagali się, by to już nastąpiło, a Bóg uwzględnił ich wołanie. Pomimo całej swej nieograniczonej władzy i suwerenności Bóg uzależnia swoją ingerencję

21 Te wypowiedzi są ujęte w każdym wydaniu Hagady, zob. np. Sefer habrachot leszabatot wechagim bemiszpacha [Księga błogosławieństw na szabaty i święta w rodzinie], Tel-Awiw 2006, s. 90-91. 
od naszej woli. Mamy zatem kolejny dowód na to, jak wielki wpływ mamy na historię zbawienia i na to, czy i w jakim zakresie, i nawet w jakim czasie Bóg podejmie te czy inne działania.

Warto szczegółowo przeanalizować trzy ważniejsze elementy wydarzeń związanych ze złamaniem szóstej pieczęci: (1) destrukcja świata materialnego, (2) przerażenie wszystkich jego mieszkańców oraz (3) gniew Baranka.

\section{Poruszenie kosmosu}

Nie da się nie zauważyć, że gniew Boga jest opisywany w proroctwach w połączeniu z zachwianiem się świata materialnego, który w codziennym ludzkim doświadczeniu wydaje się absolutnie niewzruszonym i trwałym. Iluzję niewzruszoności materii podtrzymują współcześnie narracje naukowe przesiąknięte ideologią materialistyczną ${ }^{22}$ wbrew oczywistym ustaleniom kosmologii. Można bowiem wykazać, że stwierdzony fakt rozprężania wszechświata nieuchronnie prowadzi do stopniowego rozrywania wszystkich istniejących w nim struktur materialnych, począwszy od galaktyk i kończąc na atomach ${ }^{23}$.

Tę pozorną trwałość od wieków kwestionują różne teksty biblijne, wskazując na stopniową nieodwracalną degradację materii ${ }^{24}$, która w czasach nowożytnych została uznana za prawo naukowe ${ }^{25}$. Od pierwszej chwili funkcjonowania dowolnego wyrobu inżynierskiego materiał ulega degradacji, a jego właściwości się pogarszają. Nie istnieje żadna metoda, która w stu procentach zatrzymałaby degradację materiału ${ }^{26}$. Zatem w świetle obecnej

22 Newton jeszcze odwoływał się do bezpośredniego działania Boga w fizyce ciał niebieskich, ale sto lat później Laplace już nie miał takiej potrzeby. Ostatecznie upowszechnienie hipotez Darwina doprowadziło do eliminacji odniesień do Boga w naukach przyrodniczych (A. Zabołotny, Naturalizm metodologiczny w nauce - dylemat teisty, „Filozoficzne Aspekty Genezy” 13 (2016), s. $25-48)$.

23 Z. Jacyna-Onyszkiewicz, Możliwość stopniowego rozrywania struktur wszechświata, „Nauka” 2 (2009), s. 151-156.

24 „Ty niegdyś założyłeś ziemię i niebo jest dziełem rąk Twoich. Przeminą one, Ty zaś pozostaniesz. I całe one jak szata się zestarzeją" (Ps 102, 26-27).

25 „Krótko mówiąc, entropia jest miarą nieuporządkowania molekularnego. Prawo nieodwracalnego wzrostu entropii [nieuporządkowania] jest prawem postępującej dezorganizacji, aż do pełnego zaniku warunków początkowych” (I. Prigogine, Can thermodynamics explain biological order?, „Impact of Science on Society” 23 (1973) nr 3, s. 162).

26 A. W. Batchelor, Loh Nee Lam, M. Chandrasekaran, Materials degradation and its control by surface engineering, London 2011, s. 1-2). 
wiedzy o świecie materialnym i zasadach jego funkcjonowania teza o wiecznym trwaniu materii w znanej nam postaci jest nie do utrzymania.

Jednak wizja św. Jana ma zupełnie inny wydźwięk niż stopniowa degradacja starzejącego się materiału. Została mu ukazana sytuacja, w której gniew Boży spowoduje gwałtowną, zauważalną, totalną destrukcję otaczającego nas świata. Dokładne zbadanie tekstu wskazuje na liczne paralele do innych tekstów objawionych, jednak nie jest to proste wykorzystanie znanej symboliki ani przytaczanie fragmentów wcześniejszych utworów. Teksty Apokalipsy wskazują na tę samą rzeczywistość, ale używają nieco innych obrazów i sformułowań. Jan bowiem musiał zobaczyć coś, co później spisał (Ap 1, 9-11), a ukazane mu obrazy są zgodne z tym, co zostało objawione licznym prorokom przed nim. Tabela 1 przedstawia wersety biblijne, w których zostały wspomniane te same kataklizmy związane z ostatecznym zniszczeniem świata materialnego.

\begin{tabular}{|c|c|c|}
\hline Kataklizm & Wzmianka & Liczba wzmianek \\
\hline Słońce się zaćmi (przemieni się w ciemność) & $\begin{array}{l}\text { Iz 13, 10; II 2, 10; II 3, 4; II 3, 20; Am 8, 9; Mi 3, 6; Нa 3, 11; } \\
\text { Mt 24, 29; Mk 13, 24; Dz 2, 20; Ap 6, 12; Ap 8, } 12\end{array}$ & 12 \\
\hline Księżyc nie błyśnie swym światłem & $\begin{array}{l}\text { Iz 13, 10; Ez 32, 7; J 2, 10; ॥ 3, 20; Ha 3, 11; Mt 24, 29; } \\
\text { Mk 13, 24; Ap 8, } 12\end{array}$ & 8 \\
\hline Księżyc przemieni się w krew & $\| 3,4 ; D z 2,20 ; A p 6,12$ & 3 \\
\hline $\begin{array}{l}\text { gwiazdy niebios i ich planety } \\
\text { nie dadzą swojego światła }\end{array}$ & Iz 13, 10; Ez 32, 8; II 3, 20; Ap 8, 12 & 4 \\
\hline gwiazdy spadać będą z nieba & Dn 8, 10; Mt 24, 29; Mk 13, 25; Ap 6, 13; Ap 12, 4 & 5 \\
\hline będą znaki na Słońcu, Księżycu i na gwiazdach & $Ł k 21,25$ & 1 \\
\hline $\begin{array}{l}\text { niebo się zatrzęsie, zwinie się, } \\
\text { niebiosa rozwieją się jak dym }\end{array}$ & $\begin{array}{l}\text { Iz 34, 4; Iz 51, 6; Jr 2, 12; II 2, 10; J 3, 21; Ag 2, 6; Mt 24, 29; } \\
\text { Mk 13, 25; tk 21, 26; Hbr 12, 26; } 2 \text { P 3, 10; Ap 6, } 14\end{array}$ & 12 \\
\hline ziemia zadrży, rozpadnie się & Iz 51, 6; Jl 2, 10; J 3, 21; Na 1, 5; Hbr 12, 26; Ag 2, 6; Ap 6, 12 & 7 \\
\hline morze poruszy się, zostanie wysuszone & Ps 18,6 ; Iz 50, 2; Na 1, 4; Ag 2, 6; Łk 21, 25 & 5 \\
\hline morze przemieni się w krew & Ap 8,8 & 1 \\
\hline palący ogień & II3, 3; Na 1,6;2P3, 7;2P3, 10;2P3, 12; Ap 16, 8 & 6 \\
\hline
\end{tabular}

Powyższe zestawienie pokazuje, że „dzień gniewu” nie ogranicza się jedynie do zmiany ekipy rządzącej, jak chcieliby niektórzy egzegeci. Ze wszelkim prawdopodobieństwem należy przyjąć, że niebo ulegnie destrukcji, skoro 
12 razy w 10 księgach otrzymaliśmy takie zapewnienie sformułowane na różne sposoby. W żadnym z tych tekstów nie ma wskazówek sugerujących, że chodzi o retoryczny zabieg lub figurę hiperboliczną.

Kilkadziesiąt razy Bóg zasygnalizował przez autorów Biblii, że kiedy nadejdzie Jego gniew, cały świat materialny ulegnie zniszczeniu. Lekceważenie tych ostrzeżeń wydaje się nierozsądnym; a z pewnością ludzie nie będą mieli wymówki w dniu gniewu, że nie wiedzieli, iż to będzie tak wyglądało.

\section{Przerażenie ludzi}

Opisując przerażenie mieszkańców ziemi, Apokalipsa wymienia wszystkie znane w tamtych czasach warstwy społeczne (królowie ziemscy, wielmoże i wodzowie, bogacze i możni, i każdy niewolnik, i wolny), nie pomijając nawet niewolników. Wszyscy bez wyjątku okazują się bezradni i napełnieni lękiem wobec materializującego się w kataklizmach gniewu Bożego, który dotknie wszystkich. Brzmi rozpaczliwe pytanie: „Kto może się ostać?” (Ap 6, 17), i wydaje się, że nikt nie zostanie ocalony. Psalmista bowiem podpowiada, że nieprzebaczone grzechy eliminują możliwość ocalenia (Ps 130, 3).

Obraz przerażenia z powodu gniewu Bożego powtarza się w wielu księgach biblijnych, na przykład:

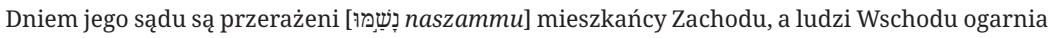
zgroza (שָׁע sa’ar) (Hi 18, 20 Biblia Warszawska).
}

Biadajcie! Bo bliski jest dzień Pana, który nadchodzi jako zagłada od Wszechmocnego. Dlatego opadają wszystkie ręce i truchleje każde serce ludzkie. I są przerażeni [וְְְָ w-niwlahu]; ogarniają ich kurcze i bóle, wiją się z bólu jak rodząca, jeden na drugiego spogląda osłupiały, ich oblicza są rozpłomienione (Iz 13, 6-8 Biblia Warszawska);

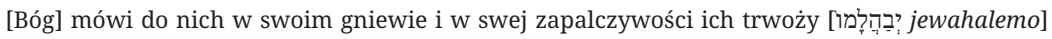
(Ps 2, 5 Biblia Tysiąclecia)

Prorok Nahum opisuje bardziej szczegółowo wydarzenia związane z eschatologicznym gniewem Pana, oddając wszechogarniający lęk ludzi słowami: „omdlewa”, „więdnie kwiat”, „trzęsą się wszyscy mieszkańcy”, a jednocześnie zwraca uwagę czytelnika na granice cierpliwości Boga: 
Pan jest cierpliwy, ale i potężny siłą; a oczyszczając - nikogo nie zostawia bez kary. Wśród burzy i wichru Jego droga, a chmury - pyłem nóg Jego. On gromi morze i On je wysusza, i wszystkie rzeki zamienia w pustynię. Omdlewa Baszan i Karmel i więdnie kwiat Libanu. Przed Nim drżą góry i pagórki się rozpływają; a ziemia trzęsie się od Jego oblicza -i ląd, i wszyscy jego mieszkańcy. Któż się ostoi przed Jego zagniewaniem i kto wytrzyma Jego zapalczywość? Gniew Jego wylewa się jak ogień; i rozpadają się przed Nim skały (Na 1, 3-6).

Natychmiast po tym opisie ogólnoludzkiego lęku Nahum pokazuje, że nawet w tej przerażającej sytuacji walącego się świata materialnego jest możliwość „ostania się” wobec „zagniewania i zapalczywości” Boga: „Dobry jest Pan, On obroną w dniu niedoli; zna tych, którzy Mu ufają” (Na 1, 7).

Podobnie Apokalipsa św. Jana roztaczając przerażającą wizję rozpadającego się kosmosu nie pozostawia ludzi bez nadziei. Trzeba tylko zadać sobie trud i odnaleźć w tym przesłaniu wskazówkę, „kto może się ostać” w dniu gniewu Baranka.

\section{Gniew Baranka}

Dlaczego jest mowa o gniewie Baranka? Czym jest „gniew Baranka” (ỏpyń

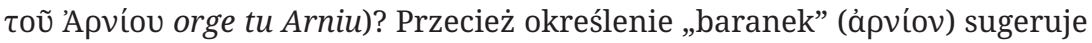
łagodność i spokój charakterystyczne dla tego zwierzęcia. Co innego, gdyby była mowa o wściekłym gniewie młodego lwa ${ }^{27}$, to by brzmiało groźnie, ale trudno nawet sobie wyobrazić rocznego baranka unoszącego się gniewem!

Poczynając od tekstu Ap 6, 1, Baranek jawi się jako postać bardzo aktywna w historii, która dzięki swojej wyjątkowej potędze kieruje wydarzeniami kosmicznymi ${ }^{28}$. W kontekście sądu ostatecznego i dnia Pańskiego autorzy tekstów Starego Testamentu nieraz używają wyrażenia „dzień gniewu” (יị jom af),

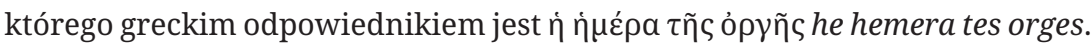
Zapewne dodając słowo $\mu \varepsilon \gamma a ́ \lambda \eta$ megale (,wielki”), Apostoł Jan chciał podkreślić, że mowa jest nie o jakimś tam gniewie, tylko o „palącym gniewie” Boga

27 Takie sformułowanie można znaleźć w komentarzach do ksiąg prorockich znalezionych w Qumran, np. papirus 4Q167 (P. Muchowski, Rękopisy znad Morza Martwego, Kraków 1996, s. 114).

28 T. Tułodziecki, “L'ira dell'Agnello” nell’Apocalisse di san Giovanni (6, 16-17), „Biblica et Partistica Thoruniensia” 6 (2013), s. 207-227, http://dx.doi.org/10.12775/BPTh.2013.012. 
(חָר charon af), albo też nie o jakimś tam dniu gniewu, tylko o tym właśnie wielkim, przerażającym, ostatnim dniu gniewu Bożego. Warto odnotować, że w Peszitcie w wersecie Ap 6, 16 na oznaczenie gniewu został użyty wyraz , ถַمُ์ âfāw(hi), którego nie odnotowują w tym znaczeniu dostępne słowniki $^{29}$. Ewidentnie tłumacz wykorzystał hebrajski rdzeń §ֵ af, nawiązując do biblijnego pojęcia יִ jom af (,dzień gniewu”), a w wersecie 17 podał

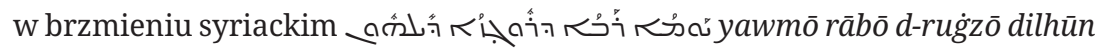
(„wielki dzień ich gniewu”).

Rabini Talmudu, rozważając zagadnienie „dnia gniewu”, wyciągają wnioski, że ukryta dobroczynność (nie na pokaz) odwraca gniew Boży, podczas gdy sędzia biorący łapówki ściąga gniew Boży na świat (Bawa basra, 9b). Nieco dalej wyrażona jest opinia, że bogactwo nie przyniesie żadnej korzyści w dniu gniewu, podczas gdy jałmużna (po hebrajsku צדקה cedaka, dosł. „sprawiedliwość”) może wyratować od śmierci (Bawa basra, 10a). Śmierć w tym przypadku jest rozpatrywana w kategoriach zarówno śmierci fizycznej, jak i duchowej (eschatologicznej) w odniesieniu do So 1, 15.

Musimy przyjąć, że Boży gniew nie jest gniewem emocjonalnym, jak w przypadku ludzi, ale jest funkcją Bożej miłości. Bóg taki, jakim przedstawia go słowo Boże, nie może i nie będzie stał zawsze biernie wobec cierpienia swojego ludu. Jego reakcją na grzech, który niszczy jego stworzenie, jest sprawiedliwy sąd, i to właśnie z tego sądu wynika gniew Boga opisywany w Biblii. Bóg potępia grzech na sądzie i prowadzi do jego całkowitego usunięcia. Kulminacyjną fazą dzieła Baranka jest zaprowadzenie, zrealizowanie postanowień sądu dotyczących każdego mieszkańca ziemi, a zatem wykonanie wyroku sądu. To właśnie jest nazywane „gniewem Bożym” lub „gniewem Baranka”, co nie ma nic wspólnego z ludzkim pojęciem gniewu. Zauważmy, że Bóg i Baranek występują tutaj zamiennie.

Gniew ludzki ma zupełnie inny charakter. Człowiek nie jest sprawiedliwy i nie może reagować adekwatnie na grzech, realizując prawomocne wyroki. Dlatego nie możemy usprawiedliwiać swojego gniewu, odwołując się do tego, że w Biblii pojawia się pojęcie „gniew Boży”.

Ludzki gniew, obok lęku, złości, nienawiści, wstydu, poczucia winy, jest zaliczany do negatywnych emocji, które należy redukować na drodze działań

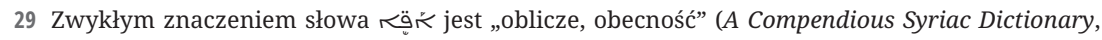
dz. cyt., s. 25). 
terapeutycznych ${ }^{30}$. Warto w tym kontekście wyszczególnić, w jaki sposób autorzy biblijni oceniają gniew człowieka:

- gniew człowieka nie czyni tego, co jest sprawiedliwe u Boga (Jk 1, 20),

- jest istotna różnica pomiędzy gniewem człowieka a gniewem Boga (Rz 12, 19-21),

- każdy, kto się gniewa na brata swego, pójdzie pod sąd (Mt 5, 22),

- gniew jest przeklęty (Jakub o zachowaniu swoich synów) (Rdz 49, 7),

- gniew przeszkadza w modlitwie (1 Tm 2, 8),

- gniew jest uczynkiem ciała obok czarów i zabójstwa (Ga 5, 20),

- Paweł nie chce zastać u Koryntian gniewu i swary (2 Kor 12, 20).

Człowiek, który się gniewa, jest oceniany przez autorów biblijnych jednoznacznie negatywnie i często nazywany jest głupim:

- gniew mieszka w piersi głupców (Koh 7, 9),

- głupi od razu okazuje swoją złość, lecz mądry nie zważa na obelgę (Prz 12, 16),

- głupi ujawnia całą swoją porywczość (Prz 29, 11),

- $\quad$ człowiek nieopanowany jest jak miasto z rozwalonym murem (Prz 5, 28).

Didache doradza: „Nie bądź gniewliwym, bowiem gniew prowadzi do zabójstwa” $(3,2)^{31}$. Zwoliński podkreśla, że gniew jest wymieniony jako pierwszy na liście grzechów wywołujących gniew Boży (Kol 3, 7-8), a człowiek opanowany przez zło łatwo przechodzi od mniejszych występków do ciężkich przestępstw, coraz poważniej narusza porządek naturalny ustanowiony przez Boga i wywołuje tym samym coraz silniejszy gniew Boga ${ }^{32}$.

Uderzającym sformułowaniem na końcu poselstwa szóstej pieczęci jest „dzień gniewu ich” - czyli Boga Ojca i Baranka Bożego. Niewątpliwie św. Jan odwołuje się do całego aparatu pojęciowego oraz do bogatych w treść obrazów biblijnych. Przez wieki bowiem prorocy zapowiadali i opisywali dzień gniewu Pana, tutaj natomiast ponownie ukazana jest niepojęta jedność Boga Ojca i Syna Bożego.

Opis złamania szóstej pieczęci kończy wołanie przerażonych ludzi, a wołanie to zawiera cenną wskazówkę co do tożsamości tych, którzy będą mogli

30 I. Niewiadomska, Dynamika cierpienia u osób uzależnionych: porównanie doświadczeń alkoholików pijących i alkoholików w okresie wczesnej abstynencji, [w:] Cierpienie. Między sensem a bezsensem. Studium interdyscyplinarne, red. M. Kalinowski, I. Niewiadomska, L. Szot, Łuck 2014, s. 127-148.

31 Didache, czyli Nauka Dwunastu Apostołów, przekł. J. Jankowski, Warszawa 1923, s. 14.

32 A. Zwoliński, Katalog grzechów wołających o pomstę do nieba, [w:] Wielopłaszczyznowe wsparcie człowieka we wspótczesnej pedagogii, red. nauk. R. Pikuła, Kraków 2011, s. 517-532. 
jednak się ostać przed tronem oraz przed gniewem Baranka. Panujący i poddani, wielcy i mali, prości i wykształceni, wszyscy próbują ukryć się przed Jego obliczem. Wszyscy, którzy wzgardzili łaską Boga, odczuwają przerażenie, które rodzi pytanie: „Kto może się ostać przed Jego gniewem?”. Odpowiedzią na to pytanie jest kolejny rozdział Księgi Objawienia, który nie jest już przedmiotem niniejszego studium.

\section{Podsumowanie}

Wizje św. Jana mające na celu odsłonięcie tajemnicy Boga i będące świadectwem Jezusa Chrystusa odnotowują przełomowy moment w historii świata. W chwili złamania szóstej pieczęci w odpowiedzi na wołanie sprawiedliwych łagodny Baranek złożony na ofiarę za nasze grzechy radykalnie zmienia swoje podejście do ludzkości. Rozpoczyna się dzień gniewu Bożego, który jest jednocześnie dniem gniewu Baranka, a któremu towarzyszą przerażające zjawiska zmierzające do destrukcji całego świata materialnego.

Zapalczywość gniewu Baranka jednak nie ma nic wspólnego z ludzkim uniesieniem. Gniew ten jest reakcją na bezprawie i krzywdy wyrządzane przez ludzi, którzy nie uznają władzy Boga nad światem ani Jego praw. Żaden człowiek nie ma takiej sprawiedliwości uprawniającej do gniewania się na innych, dlatego też teksty biblijne wielokrotnie kwalifikują gniew ludzki jako zło.

Wobec poruszenia kosmosu, który dotąd wydawał się trwałym i niewzruszonym, przerażeni ludzie usiłują się ukryć przed gniewem Boga Ojca i Baranka Bożego. W myśl interpretacji Andrzeja z Cezarei jest to ostatni moment pozostawiony człowiekowi na pokutę i nawrócenie. Nasuwa się mimowolne skojarzenie ze słowami Jana Chrzciciela: „Plemię żmijowe, kto wam pokazał, jak uciec przed nadchodzącym gniewem?” (Mt 3, 7).

\section{Abstrakt}

\section{Zerwanie szóstej pieczęci i „dzień wielki gniewu ich" (Ap 6, 17)}

W artykule przeanalizowano zagadnienie gniewu Baranka pojawiającego się w opisie wizji złamania szóstej pieczęci w Księdze Objawienia (Ap 6, 17). Gniew Baranka jest czymś niezwykłym i paradoksalnym sam w sobie, gdyż baranek nie jest zwierzęciem kojarzącym się z gniewem. Dlatego też w badaniach zazwyczaj więcej uwagi poświęca się zwycięstwu Baranka i Jego chwale, a także roli, jaką odegrał w zbawieniu ludzi, i Jego uczcie weselnej. Niniejsze studium obejmuje kontekst złamania szóstej pieczęci 
oraz następujących po nim plag i nieszczęść z odniesieniami do literatury rabinicznej i tekstów innych ksiąg biblijnych. Osobno omówiono poruszenie kosmosu oraz przerażenie ludzi spowodowane gniewem baranka. Dokonano też porównania gniewu ludzkiego z gniewem Bożym.

Słowa kluczowe: gniew Boży, Baranek Boży, Apokalipsa, eschatologia

\section{Abstract}

\section{Opening of the sixth seal and "the great day of their wrath" (Revelation $6: 17$ )}

In the paper, the issue of the Lamb's wrath connected with the opening of sixth seal in the Book of Revelation $6: 17$ is analyzed. The Lamb's wrath is itself unusual and paradoxical, because a lamb is not an animal associated with wrath. Hence, in the biblical studies, more attention is paid to the victory and glory of the Lamb, and to His role in the salvation of human beings, as well as to His marriage supper. The present study covers the context of sixth seal opening and subsequent plagues and disasters with references to Rabbinic literature and Biblical passages. In particular, the shake of universe and horror of people are discussed. In addition, the comparison of human anger and God's wrath was performed.

Keywords: God's wrath, God's Lamb, Revelation, eschatology

\section{References}

Batchelor, A. W., Loh Nee Lam, \& Chandrasekaran, M. (2011). Materials degradation and its control by surface engineering. Imperial College Press. http://www.books24x7.com/marc.asp?bookid=13493

Biblia to jest całe Pismo Święte Starego i Nowego Testamentu z hebrajskiego i greckiego języka na polski pilnie i wiernie przettómaczona. (1986). Brytyjskie i Zagraniczne Towarzystwo Biblijne.

Biblia to jest Pismo Święte Starego i Nowego Testamentu. (1975). Brytyjskie i Zagraniczne Towarzystwo Biblijne. Holbrook, F. B. (Ed.). (1992). Symposium on Revelation. Introductory and Exegetical Studies: Vol. Book 1-2. Biblical Research Inst.

Jacyna-Onyszkiewicz, Z. (2009). Możliwość stopniowego rozrywania struktur wszechświata. Nauka, 2, 151-156. Jankowski, J. (Ed.). (1923). Didache, czyli nauka dwunastu Apostołów. Księgarnia Kuncewicza i Hofmana.

Jasiewicz, A. (2012). Interpretacja „Komentarza do Apokalipsy” Andrzeja z Cezarei i jego znaczenie dla krytyki tekstu biblijnego. Biblica et Patristica Thoruniensia, 5, 163-174. https://doi.org/10.12775/BPTh.2012.009

Karczewski, M. (2012). Jezioro siarki i ognia w Księdze Apokalipsy św. Jana. Biblica et Patristica Thoruniensia, 5, 103-114. https://doi.org/10.12775/BPTh.2012.005

Klinkowski, J. (Ed.). (2010). Apokalipsa (H. Langkammer, Trans.). Wydawnictwo KUL.

Kotecki, D. (2008). Kościót w świetle Apokalipsy św. Jana. Święty Paweł.

Kotecki, D. (2013). Jezus a Bóg Izraela w Apokalipsie św. Jana. Wydawnictwo Naukowe Uniwersytetu Mikołaja Kopernika.

Langkammer, H. (2010). Apokalipsa św. Jana. Realia archeologiczno-historyczne w wizjach i symbolice. TUM Wydawnictwo Wrocławskiej Księgarni Archidiecezjalnej.

Muchowski, P., \& Kapera, Z. J. (Eds.). (1996). Rękopisy znad Morza Martwego. The Enigma Press.

Naumowicz, J. (2011). Pierwsze interpretacje Apokalipsy. In D. Budzanowska \& W. Linke (Eds.), Pierwsze tacińskie komentarze do Apokalipsy. Hipolit, Wiktoryn, Hieronim, Tykoniusz (pp. 7-48). Wydawnictwo Uniwersytetu Kardynała Stefana Wyszyńskiego. 
Niewiadomska, I. (2014). Dynamika cierpienia u osób uzależnionych: Porównanie doświadczeń alkoholików pijących i alkoholików w okresie wczesnej abstynencji. In M. Kalinowski, I. Niewiadomska, \& L. Szot (Eds.), Cierpienie między sensem a bezsensem. Studium interdyscyplinarne (pp. 127-148). Схıдноєвропейський нациннальний університет ıмені Лесı Українки.

Payne Smith, J. (1998). A compendious Syriac dictionary. Eisenbrauns.

Pismo Święte Starego i Nowego Testamentu. Najnowszy przekład z języków oryginalnych z komentarzem. (2008). Święty Paweł.

Pismo Święte Starego i Nowego Testamentu w przekładzie z języków oryginalnych ze wstępami i komentarzami (3rd ed.). (1999). Księgarnia św. Wojciecha.

Popowski, R., \& Wojciechowski, M. (Eds.). (1997). Grecko-polski Nowy Testament. Wydanie interlinearne z kodami gramatycznymi (6th ed.). Vocatio.

Prigogine, I. (1973). Can thermodynamics explain biological order. Impact of Science on Society, 23(3), 159-179.

Rucki, M. (2019). Contradiction between the laws "Thou shalt not avenge" and "An eye for an eye." In C. Korzec (Ed.), Bible caught in violence (pp. 49-58). Peter Lang.

Rucki, M., \& Szymański, K. (2015). Monotrynitarne powitanie w Apokalipsie. Scriptura Sacra, 19, 183-197.

Sefer habrachot leszabatot wechagim bemiszpacha. (2006). Matan Amnujot.

Tułodziecki, T. (2013). “'́ira dell'Agnello” nell'Apocalisse di san Giovanni (6, 16-17). Biblica et Patristica Thoruniensia, 6, 207-228. https://doi.org/10.12775/BPTh.2013.012

Zabołotny, A. (2016). Naturalizm metodologiczny w nauce - dylemat teisty. Filozoficzne Aspekty Genezy, 13, 25-48.

Zwoliński, A. (2011). Katalog grzechów wołających o pomstę do nieba. In R. Pikuła (Ed.), Wielopłaszczyznowe wsparcie człowieka we wspótczesnej pedagogii. Wydawnictwo WAM. 